\title{
A Field Study of the Relationship between Leg Structure Scores and Survivability, Backfat Thickness and Behavior in Stalled Female Pigs
}

\author{
Mai KANEKO*, Yosuke SASAKI, Yasutaka TAKAI and Yuzo KOKETSU \\ School of Agriculture, Meiji University, Kanagawa, Japan 214-8571 \\ (Received : 15 September, 2009/Accepted : 10 November, 2009)
}

\begin{abstract}
Summary
The objectives of the present study were to apply leg structure scores (LSS) to examine the leg structures in stalled females, to assess the occurrence of poor leg structures, to investigate any associations between LSS and backfat thickness or behavior, and to compare the survival probabilities between LSS groups. A commercial farm equipped with a computerized recording system was visited six times over two years to record the LSS in the four legs of 709 stalled females. The structures were scored by trained evaluators when a female was standing in a gestation stall. In our scoring method (POOR or OK), the POOR leg structure was defined as buck-kneed front legs, sickle-hocked hind legs or post-legged hind legs. Females having at least one POOR leg were classified into the POOR group and the other females were classified into the OK group. We recorded the relative frequencies $(\%)$ of three types of postural behavior (standing, sitting or lying) and vacuum chewing in stalled females by point sampling at 15-minute intervals over a six hour period when the leg evaluators were recording LSS during our farm visits. Linear mixed-effects models and survival analysis were performed. The mean value $( \pm \mathrm{SEM})$ of observed parity for the 1,560 four-leg observations in 709 females was $1.9 \pm 0.04$. Relative frequencies in the POOR and OK groups were $6.4 \%$ and 93.6\%, respectively. LSS was recorded more than twice in 69.8\% (495 females) of the 709 females. The LSS in $86.5 \%$ (428 females) of these 495 females did not change across parity. Proportions of females having the POOR leg structures in parity $0,1,2,5$ and 6 were lower than those in parity 3 and 4 sows $(P<0.05)$. No differences were found between the LSS groups for hazards of culling, backfat measurements or any types of behavior of females $(P>0.10)$. In summary, stalled females having POOR or OK leg scores similarly survived. Furthermore, the LSS of stalled females was not related to backfat thickness or behavior.
\end{abstract}

Keywords : behavior, leg, sow, survival analysis, well-being

\section{Introduction}

Lameness in swine is one of the concerns about an animal well-being ${ }^{10)}$ and poor leg structure is a main reason for lameness ${ }^{9)}$. An educational tool of leg structure scores (LSS) has been developed to help producers and veterinarians to evaluate the leg structure of gilts at herd entry ${ }^{18)}$. It may also be useful for producers and veterinarians to evaluate the leg structures of stalled gilts and sows in order to identify female pigs (females) exhibiting locomotor problems such as leg

* Corresponding author :

Mai KANEKO

Higashi-mita 1-1-1, Tama-ku, Kawasaki, Kanagawa, Japan 2148571

Phone : 81-44-934-7826 ; Fax : 81-44-934-7902

E-mail : ef60032@isc.meiji.ac.jp weakness and lameness. However, no study has yet applied this evaluation method to examine the leg structures of stalled gilts and sows.

Females culled due to locomotor problems were removed from farms before they attain full life expectancy on farms ${ }^{11)}$. The average parity of females culled for locomotor problems was $2.6^{14)}$. Additionally, females with poor leg structures at herd entry were removed earlier than well-conformed gilts ${ }^{6,21)}$. To our knowledge, the relationships between the LSS in stalled females and survivability or culling risk has not been studied yet.

Culls for locomotor problems tended to be more common for low-parity females ${ }^{5,14)}$. In a previous report, 12 to $16 \%$ of removed females in low-parity females were removed due to poor leg structure ${ }^{21)}$. However, no study has reported on the occurrence of poor leg structures by parity or changes in leg 
structures across parity.

The previous studies have reported associations between lameness and thinner backfat thickness ${ }^{20)}$ or higher occurrence of lying-down behavior ${ }^{2}$ in sows. Purebred sows with backfat thickness under $15 \mathrm{~mm}$ at first farrowing tended to be culled due to lameness ${ }^{20)}$. Additionally, severe lameness in lactating sows was associated with higher occurrence of lying-down behavior ${ }^{2)}$. On the other hand, we are unaware of any studies reporting the relationship between poor leg structure and stereotype. Stereotype was defined as behavior that is relatively invariant, regularly repeated, and without an obvious function ${ }^{8}$. Vacuum chewing (one kind of stereotypies) is often used as an indicator of animal well-being ${ }^{1,8)}$. Therefore, the objectives of the present study were to apply LSS for leg structure evaluation, to assess the occurrence of poor leg structure by parity and to investigate the associations of LSS with survivability, culling risk, backfat thickness and behavior in stalled females.

\section{Materials and methods}

\section{Farm}

The present study was conducted on a commercial farm in Eastern Japan that had approximately 500 females and used a computerized recording system (PigCHAMP Inc., Ames, IA, U.S.A.). Approximately $90 \%$ of breeding females on this farm were $F_{1}$ crossbreds between Landrace and Large White, and the remaining 10\% were Landrace pigs. Homegrown gilts were selected for normal leg structures and sound gaits at various growing stages of the gilts on the farm. The sides of the gestating stalls were formed by thermostatically controlled curtains for natural ventilation. Females, including both gilts and sows, were housed in stalls on a partially slatted concrete floor after insemination. The mean ( \pm SEM) dimensions of the stalls on the farm were $219.0 \pm 2.01 \mathrm{~cm}$ long, $63.0 \pm 0.17 \mathrm{~cm}$ wide and $108.2 \pm 0.74 \mathrm{~cm}$ high. Stalled females were fed daily an average $2 \mathrm{~kg}$ of a gestation diet of corn and soybean meal in the morning. The calculated composition of the gestation diet was $13.2 \% \mathrm{CP}, 0.9 \% \mathrm{Ca}$, $0.8 \% \mathrm{P}$, and $3,180 \mathrm{kcal} / \mathrm{kg}$ of ME (as-fed basis).

Data

We visited the farm six times over two years from 2006 to 2007 to record the LSS in stalled females. We recorded 1,644 four-leg observations on 743 stalled females. Of the 743 females, 709 farrowed at least once, and had litter performance records and 1,560 four-leg observations. Thus, we analyzed 1,560 four-leg observations on the 709 females. In addition, we collected 1,419 backfat measurement records and 1,383 behavior records during the parity in which we conducted the 1,560 four-leg observations. Sow performance data, recorded using PigCHAMP, were collected after the leg observations.

\section{Definition of leg structure score}

Structures for four legs in a female were scored by trained evaluators when the female was standing in the stall. The LSS was developed by Iowa State University and National Pork Board (Ames, IA, U.S.A.). The original scoring system for replacement gilts in pens or paddock has three scores : GOOD, OK and CULL (Table 1). To check consistency of the LSS, 20 females were randomly selected and their 80 legs were scored by two independent evaluators. Kappa statistics were calculated to estimate the levels of agreement between the two evaluators ${ }^{19)}$. We combined GOOD with OK scores because our kappa value to distinguish GOOD from OK in stalled females was low (0.40) in our preliminary analysis. In our simplified scoring method, the POOR leg structure was defined as buck-kneed front legs, sickle-hocked hind legs or post-legged hind legs. Additionally, stalled females were classified into two groups based on the LSS : POOR or OK groups. Females in the POOR group had at least one leg with a POOR score, and females in the OK group had no POOR score for any leg.

In another preliminary analysis, no differences were found in the relative frequency of LSS between the left and right legs in either the front or hind legs $(\mathrm{P}>0.10)$. Additionally, no difference was found in the relative frequency of LSS between the front and hind legs $(P>0.10)$.

Point sampling for postural behavior and vacuum chewing

Our behavior observers performed six-hour point sampling ${ }^{16)}$ when leg evaluators were checking the LSS in the stalled females. In the point sampling, the observers walked quietly along the rows of stalled females and recorded three types of postural behavior (standing, sitting or lying) and vacuum chewing at 15 -minute intervals for six hours by point sampling starting from the end of the morning feed distribution (scheduled between 0730 and 0800). Relative frequencies of the postural behavior and vacuum chewing during the six hours were expressed as a percentage of the total 25 time observations. As the standard definitions ${ }^{17)}$, standing was a posture in which a female was upright with all four feet on the ground, sitting was a posture in which a female had her rear end on the floor with two front feet on the ground and lying was a posture in which a female was neither standing nor sitting. Vacuum chewing was defined as oral activity with saliva, but no with food in the pig's mouth.

\section{Definitions of culling risk and sow performance}

Culling risk in each parity was calculated as the number of females culled at subsequent parity divided by the number of females observed for leg structure at each parity $\times 100$. The culled sows did not include dead or euthanized animals.

Backfat thickness was determined approximately six $\mathrm{cm}$ off the midline of the last rib by a farm worker, using Renco Lean-meater $^{\circledR}$ (Renco Corp., Minneapolis, MN, U.S.A.). 
Table 1 Scoring system for evaluating the leg structures

\begin{tabular}{ccl}
\hline $\begin{array}{c}\text { Scores in the } \\
\text { present study }\end{array}$ & $\begin{array}{c}\text { Reference } \\
\text { score }^{1}\end{array}$ & \multicolumn{1}{c}{ Leg structure } \\
\hline POOR & CULL & $\begin{array}{l}\text { Buck-kneed front legs } \\
\text { Sickle-hocked or post-legged hind legs }\end{array}$ \\
OK & OK & $\begin{array}{l}\text { Soft or weak front pasterns on the front legs } \\
\text { Soft pasterns on the hind legs } \\
\text { OK }\end{array}$ \\
GOOD & Normal leg structure \\
\hline
\end{tabular}

${ }^{1}$ Stalder et al., 2005, Iowa State University and National Pork Board ${ }^{18)}$.

The backfat thickness at prefarrowing was measured when females were moved to a farrowing barn one week before the expected farrowing date. The backfat thickness at weaning was measured within three days before weaning. The backfat gain during gestation was calculated as the backfat thickness at weaning subtracted from the backfat thickness at prefarrowing. The stage of gestation was the number of days from the date of first mating during the conception service to the date we observed the LSS.

\section{Statistical analysis}

All statistical analyses were done with SAS software (SAS Inst. Inc., Cary, NC, U.S.A.). Binominal data were analyzed with mixed-effects logistic regression models using the GLIMMIX procedure with contrast. Continuous data were analyzed with linear mixed-effects model using the MIXED procedure with Tukey-Kramer multiple comparisons. A chi-squared test was used to examine the differences between the frequency distributions of the LSS.

Model 1 was used to compare the proportions of females having the POOR leg structures between parity or stage of gestation. The dependent variable was whether a female had the POOR leg structures. The independent variables were parity and stage of gestation. Model 2 was performed to compare backfat thickness and culling risk between the LSS groups. The independent variables were the LSS groups and parity. Model 3 was used to compare the three types of postural behavior and vacuum chewing between the LSS groups. Arcsine transformation was performed on the postural behavior and vacuum chewing data because the measurements were expressed as a proportion ${ }^{12)}$. The independent variables were the LSS groups, parity and stage of gestation. Breeds were included in all the models. Furthermore, observed year, month and female ID were included as random effects in all the models.

A Cox proportional hazards model with PHREG procedure was used to obtain the hazards for culling at subsequent parity after a leg observation. Of 1,560 four-leg observations, the first observations for 709 females were used for survival analysis. Females culled at subsequent parity after the leg observation were treated as uncensored subjects. The number of days for uncensored females was the days from the date of the farrowing to the date of the females culled. Surviving, dead and euthanized females at subsequent parity after a leg observation were treated as censored subjects. Independent variables were the LSS and the parity. The month when we recorded the LSS was included in the model, using dummy variables to adjust for variations of the month effects.

\section{Results}

Means of observed parity and stage of gestation ( \pm SEM) were $1.9 \pm 0.04$ and $58.0 \pm 0.74$ days, respectively. Relative frequencies of the POOR and OK groups were 6.4\% (100 four-leg observations) and 93.6\% (1,460 four-leg observations), respectively. Table 2 shows the proportions of females with POOR leg structures by parity. The proportions of females with POOR leg structures in parity $0,1,2,5$ and 6 were lower than those in parity 3 and $4(P<0.05)$. The LSS groups were not associated with the stage of gestation $(\mathrm{P}>$ $0.10)$.

Table 3 shows the changes in leg structures across parity. Of the 709 females, $69.8 \%$ (495 females) were scored for LSS more than twice across parity. The LSS in $86.5 \%$ (428 females) of these 495 females did not change across parity.

Table 4 shows comparisons of culling risk, backfat thickness and behavior between the LSS groups. No differences were found between the LSS groups for culling risk, backfat measurement, postural behavior or vacuum chewing $(\mathrm{P}>$ $0.10)$.

The proportion of the females culled due to locomotor problems was $1.8 \%$ (13 females). Figure 1 shows survival curves after farrowing by LSS groups. Of the 709 females, means of observed parity were $1.1 \pm 1.52$. The hazards of culling were not associated with the LSS groups $(P>0.10)$.

\section{Discussion}

The present study was the first report about the changes of the leg structure in repeated observations of stalled females 
Table 2 Comparisons of proportions (\%) of 1,560 four-leg observations in 709 female pigs between parity groups

\begin{tabular}{cccc}
\hline $\begin{array}{c}\text { Observed } \\
\text { parity }\end{array}$ & $\begin{array}{c}\text { Number of female } \\
\text { pigs observed }\end{array}$ & $\begin{array}{c}\text { Number of female } \\
\text { pigs with POOR }\end{array}$ & $\begin{array}{c}\text { Proportions of the POOR in } \\
\text { the female pigs ( } \pm \text { SEM), \% }\end{array}$ \\
\hline 0 & 436 & 16 & $3.7 \pm 0.90 \mathrm{~b}$ \\
1 & 340 & 11 & $3.2 \pm 0.96 \mathrm{~b}$ \\
2 & 249 & 15 & $6.0 \pm 1.51 \mathrm{~b}$ \\
3 & 181 & 20 & $11.0 \pm 2.34 \mathrm{a}$ \\
4 & 185 & 26 & $14.1 \pm 2.56 \mathrm{a}$ \\
5 & 140 & 9 & $6.4 \pm 2.08 \mathrm{~b}$ \\
6 & 29 & 3 & $10.3 \pm 5.76 \mathrm{~b}$ \\
\hline
\end{tabular}

${ }^{\mathrm{a}-\mathrm{b}}$ Values (within a column) followed by different letters differ $(\mathrm{P}<0.05)$.

* POOR : Female pigs having buck-kneed front legs, sickle-hocked hind legs or post-legged hind legs.

Table 3 Number of female pigs changing of the leg structure scores in the repeated observations on 495 female pigs

\begin{tabular}{lrrrrr}
\hline \multirow{2}{*}{ Scores change } & \multicolumn{5}{c}{ Number of repeated observations } \\
\cline { 2 - 6 } & Twice & Three times & Four times & Five times & Six times \\
\hline Number of all female pigs observed & 277 & 127 & 72 & 18 & 1 \\
Female pigs not changed scores & 244 & 109 & 56 & 18 & 1 \\
$\quad$ Being POOR* consistently & 1 & 0 & 0 & 0 & 0 \\
Being OK* consistently & 243 & 109 & 56 & 18 & 1 \\
Female pigs changed from OK to POOR & 11 & 6 & 3 & 0 & 0 \\
Female pigs changed from POOR to OK & 22 & 8 & 4 & 0 & 0 \\
Female pigs fluctuated scores & 0 & 4 & 9 & 0 & 0
\end{tabular}

* POOR : Female pigs having buck-kneed front legs, sickle-hocked hind legs or post-legged hind legs.

OK : Female pigs having no POOR score for any leg.

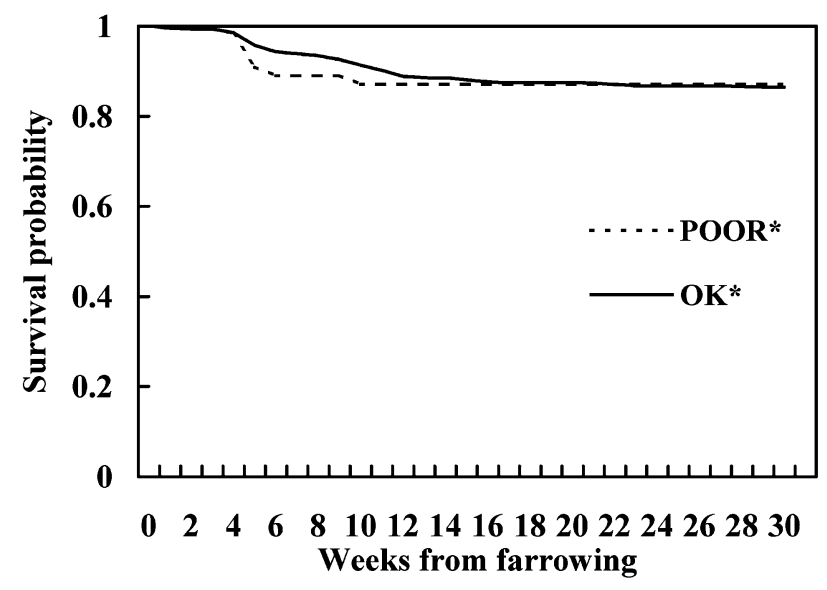

Fig. 1 Survival curves in the 709 female pigs between the leg structure score groups

* POOR : Female pigs having buck-kneed front legs, sickle-hocked hind legs or post-legged hind legs. OK : Female pigs having no POOR score for any leg. across parity. Our results showed no change of the LSS in $86.5 \%$ females across parity, which indicated that the leg structures in the stalled females did not appear to change so much across parity.

No differences between the LSS groups in survivability or culling risk indicated that the stalled females in the POOR and OK groups similarly survived. This result disagreed with some previous studies showing that the survivability decreased with poor leg structure in gilts ${ }^{6,21)}$. This discrepancy between our study and the previous studies appeared to be explained by the difference in the life stage of females when the leg structures were evaluated. We evaluated the females only in the stalls at various parities by using the LSS, whereas in the other studies the leg structures of gilts had been evaluated in parity 0 at herd entry ${ }^{6,21)}$. In fact, farm workers in this study had selected replacement gilts with desirable legs and sound gaits. Therefore, female survivability was not related to leg structures in stalled females on this studied farm. 
Table 4 Comparisons of culling risk, backfat thickness and behavior in 1,560 four-leg observations of 709 female pigs between the leg structure score groups

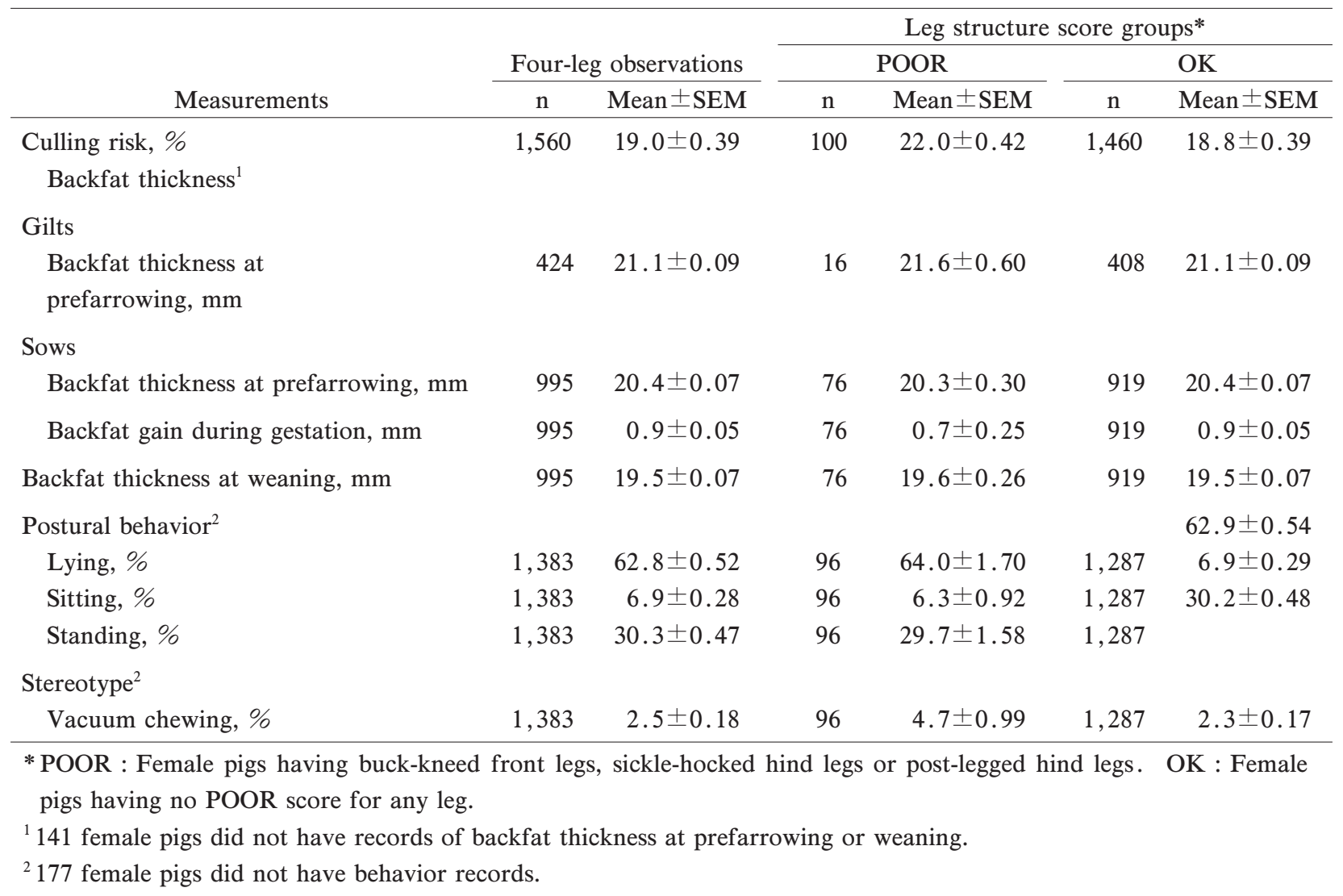

Our study showed that the females in low-parity had fewer POOR legs than those in mid-parity. Low-parity was one of the factors associated with a high occurrence of leg weakness and culling due to locomotor problems ${ }^{1,3)}$. The few lowparity females having undesirable leg structures in the present study suggested that replacement gilts had been selected for desirable leg structures before their herd entry. Additionally, there were lower proportions of sows with POOR leg structures in high-parity than those in mid-parity. The reason for this appeared to be explained that high-parity sows have long been under culling pressure for locomotor problems ${ }^{3)}$.

Our study farm had approximately only one fifth of the proportion of females with the undesirable leg structures compared to a previous study that showed 30.5\% $\%^{7)}$. Additionally, the lower proportion of the females culled due to locomotor problems in the present study $(1.8 \%)$ than that in a previous study $(8.6 \%)^{4)}$ indicated that the number of females having locomotor problems to be culled was not many on the farm.

Leg weakness was associated with a high occurrence of lying-down behavior in sows ${ }^{15)}$. However, under the condi- tions of the present study, no associations between LSS groups and postural behavior or stereotype indicate that the leg structures we observed may not be poor enough to affect leg weakness or behavior.

Our study did not find any association between the LSS groups and backfat measurements, although an influence of thin backfat thickness on locomotor problems has been reported in other studies ${ }^{13,20)}$. Probably, the females we observed were well fed and managed throughout gestation.

In conclusion, the leg structures in stalled females were not critically related to survivability, backfat measurements or behavior. We recommend checking the leg structures in replacement gilts before their herd entry rather than those in the stalled females.

\section{Acknowledgments}

The authors gratefully thank the swine producers for their cooperation for the project, and the staff members at Global Pig Farms, Inc. (Shibukawa, Gunma, Japan) for their technical assistance. We also thank Dr. I. McTaggart for his critical review of this manuscript. This research is supported by Research Project Grants from Meiji University and the 
Ministry of Education, Culture, Sports, Science and Technology of Japan.

\section{References}

1) Anil, L. and Anil, S. S. : Cortisol, behavior responses, and injury scores of sows housed in gestation stalls. $\mathbf{J}$ Swine Health Prod., 14, 196-201, 2006.

2) Bonde, M. et al. : Associations between lying-down behavior problems and body condition, limb disorders and skin lesions of lactating sows housed in farrowing crates in commercial sows herds. Livest. Prod. Sci., 87, 179187, 2004.

3) D'Allaire, S. et al. : Culling patterns in selected Minnesota swine breeding herds. Can. J. Vet. Res., 51, 506512, 1987.

4) Engblom, L. et al. : Sow removal in Swedish commercial herds. Livest. Sci., 106, 76-86, 2007.

5) Engblom, L. et al. : Factors affecting length of productive life in Swedish commercial sows. J. Anim. Sci., 86, 432-441, 2008.

6) Fernàndez de Sevilla, X. et al. : Effects of leg conformation on survivability of Duroc, Landrace, and Large White sows. J. Anim. Sci., 86, 2392-2400, 2008.

7) Fernàndez de Sevilla, $X$. et al. : Genetics background and phenotypic characterization over two farrowing of leg conformation defects in Landrace and Large White sows. J. Anim. Sci., 87, 1606-1612, 2009.

8) Fraser, A.F. and Broom, D.M. : Farm animal behavior and welfare. 363, 1974.

9) Jørgensen, B. : Effect of different energy and protein levels on leg weakness and osteochondrosis in pigs. Livest. Prod. Sci., 41, 171-181, 1995.

10) Jørgensen, B. : Longevity of breeding sows in relation to leg weakness symptoms at six month of age. Acta vet. scand., 41, 105-121, 2000.

11) Jørgensen, B. and Sørensen, M.T. : Different rearing intensities of gilts : II. Effects on subsequent leg weakness and longevity. Livest. Prod Sci., 54, 167-171, 1998.

12) Kleinbaum, D.G., Kupper, L.L. and Muller, L.E. : Applied regression analysis and other multivariable methods. 2nd ed. North Carolina Univ., North Carolina, U.S.A., 1987

13) López-Serrano, M. et al. : Genetic correlations of growth, backfat thickness and exterior with stayability in Large White and Landrace sows. Livest. Prod. Sci., 62, 121131, 2000.

14) Lucia Jr. T., Dial, G.D. and Marsh, W. : Lifetime reproductive performance in female pigs having distinct reasons for removal. Livest. Prod. Sci., 63, 213-222, 2000.

15) Marchant, J.N. and Broom, D.N. : Effects of housing system on movement and leg strength in sows. Appl. Anim. Behav. Sci., 41, 275-276, 1994.

16) Martin, P. and Bateson P. : Measuring Behavior. 2nd ed. Cambridge Univ., Cambridge, U.K., 1993.

17) Sekiguchi, T. and Koketsu, Y. : Behavior and reproductive performance by stalled breeding females on a commercial swine farm. J. Anim. Sci., 82, 1482-1487, 2004.

18) Stalder, K.J. et al. : Pocket guide for the evaluation of structural, feet, leg, and reproductive soundness in replacement gilts. Iowa State Univ., Iowa, U.S.A., 2005.

19) Stokes, M.E., Davis, C.S. and Koch, G.G. : Categorical data analysis using the SAS system. 2nd ed., 2000.

20) Tarrés, J. et al. : Factors affecting longevity in maternal Duroc swine lines. Livest. Prod., 100, 121-131, 2006.

21) Tiranti, K.I. and Morrison, R.B. : Association between limb conformation and retention of sows through the second parity. Am. J. Vet. Res., 67, 505-509, 2006. 
原 著

\title{
ストール飼育雌豚における四肢の肢勢スコアと生存時間, 背脂肪厚及び行動との関連性
}

\author{
金子麻衣*・佐々木羊介・高井康孝・䋶縝雄三 \\ ２14-8571 神奈川県川崎市多摩区東三田 1-1-1，明治大学農学部
}

\begin{abstract}
要旨
跛行や脚弱といった四肢の問題は, 動物福祉の問題に 関係していると考えられる。海外では, 農場導入時の未経 産豚における四肢の肢勢スコアが発表されているが，こ れはストール飼育された雌豚において，四肢に問題があ る雌豚を発見することに役立つかむしれない。本研究は， 生産農場において，ストール飼育された此豚豚の四肢の肢 勢を観察すること, 肢勢スコアと生存時間, 背脂肪厚及び 行動との関連性を調査することを目的とした。繁殖雌豚 500 頭一貫経営農場に 2 年間で 6 回訪問し, 雌豚の四肢の 肢勢スコアを記録した。肢勢スコアは，OK と POORに 分類した。前肢に扔いて, 肘が内側に曲がっているもの, 後肢に求いて, 尻・後膝・飛節が直線上に位置にあり直 肢している，または飛節が鎌状に曲がっているあのを POOR, POOR 以外の肢勢を OK とした。また，少なくと あ 1 本の肢の肢勢スコアが POOR であった雌豚を POOR グループ, その他の雌豚を OK グループに分類した。四肢

の肢勢スコアと生存時間の関連性には, 生存時間分析を 用い，その他の分析には混合効果モデルを用いた。709 頭 に打ける 1,560 観察記録の内, 肢勢スコアが POOR で あった記録は 6.4\% (1460記録), OKであった記録は 93.6\% (100 記録) であった。また, 四肢の肢勢を複数回観 察された 495 頭のうち，86.5\%（428 頭）は産次を経ても 肢勢スコアが变化しなかった。 $0 ， 1 ， 2 ， 5 ， 6$ 産次の雌豚 は 3 産次之 4 産次の雌豚よりあ肢勢スコアが POORで あった雌豚の割合が低くなった $(\mathbf{P}<0.05)$ 。生存確率に肢 勢スコアによる差は見られなかった。また，淘汰リスクに 肢勢スコアによる差はなかった。背脂肪厚, 行動割合と肢 勢スコアに関連性はなかった。本研究に戈いて, ストール 飼育された此豚における四肢の肢勢スコアは, 生存時間, 背脂肪厚及び行動と関連がないことを示唆した。

キーワード : 行動, 四肢, 母豚, 生存時間分析, 動物福祉
\end{abstract}

連絡先 : 金子麻衣*

明治大学農学部農学科

T214-8571 神奈川県川崎市多摩区東三田 1-1-1

Tel : 81-44-934-7826; Fax : 81-44-934-7902

E-mail : ef60032@isc.meiji.ac.jp 